\title{
Ouerleiding by Ouers wat Swart Babas met 'n Gesplete Lip en Verhemelte
}

\author{
Corrieta Campbell \& Brenda Louw \\ Departement Kommunikasiepatologie \\ Universiteit van Pretoria
}

\section{OPSOMMING}

Daar is aanduidings dat die ouers van gesplete-lip-en-verhemeltebabas dikwels behoefte toon aan meer inligting omtrent hul baba se geboortedefek as wat aan hulle verskaf word. In Suid-Afrika bestaan daar egter nog 'n leemte in die literatuur omtrent die spesifieke behoeftes van die ouers van 'n swart baba met 'n gesplete lip en verhemelte. In hierdie studie is daar eerstens ' $n$ bepaling gedoen van die ouers van swart gesplete-lip-en-verhemeltebabas se unieke behoeftes en tweedens is daar, op grond van die verkreë resultate, 'n inligtingstuk vir hierdie teikengroep saamgestel. Op grond van die resultate verkry met behulp van die vfftien proefpersone wat aan hierdie studie deelgeneem het, is daar eerstens bevind dat die ouers van swart gesplete-lip-en-verhemeltebabas in Suid-Afrika eenderssoortige behoeftes as ouers van babas met dieselfde a angebore gebrek wêreldwyd vertoon. Tweedens is daar bevind dat die inligtingstuk wat as deel van die studie saamgestel is, 'n positiewe bydrae gelewer het tot die ouerleiding wat met die proefpersone in die studie uitgevoer is. Die resultate hou dus ook belangrike terapeutiese implikasies in.

\section{ABSTRACT}

There are indications that the parents of babies with a cleft lip and palate often require more information regarding their baby's birth defect than what is given to them. In South Africa shortcomings exist in the literature covering the specific requirements of parents of black cleft lip and palate babies. In this study the unique requirements of parents of black cleft lip and palate babies was determined and, based on these results, an information pamphlet was prepared for this population group. Based on the results obtained with the help of fifteen participants it was established, firstly, that the needs of black South-Arfican parents of children with a cleft lip and palate are similar to the needs of parents of babies with the same birth defect world-wide. Secondly, it was established that the information pamphlet which was compiled as part of the study made a positive contribution to parent guidance conducted with the participants. Important therapeutic implications were also reflected by the results.

Tot op hede het die swart gesplete-lip-en-verhemeltepopulasie in Suid-Afrika weinig belangstelling uitgelok (Louw, 1986). Bestaande navorsing oor die problematiek van hierdie aangebore gebrek is slegs op geselekteerde populasies uitgevoer. Daar is op internasionale vlak 'n behoefte aan navorsing en kultureel aangepaste intérvensieprogramme oor die problematiek van die gesplete lip en verhemelte binne anderskleurige populasies en dit neem voortdurend toe (ToliverWeddirigton, 1990).

Vroeë intervensie, soos wat tans suksesvol in die blanke populasie van Suid-Afrika deur middel van ouerleiding toegepas word, kan moontlik die oplossing wees vir die uitgesproke behoefte aan hulp en leiding onder die swart bevolking (Bzoch, 1989; Brookshire; Lynch \& Fox, 1980; Louw, 1988). Die implementering van vroeë intervensie word voorgestaan omdat swart gesplete-lip-en-verhemeltepasiënte soms glad nie by ' $n$ hospitaal uitkom voordat chirargiese sluiting van die baba se lip en verhemelte plaasvind nie. Hierdie pasiënte is ook dikwels buite bereik van 'n spraakterapeut nadat hulle die hospitaal verlaat het.

Swart ouers van gesplete-lip-en-verhemeltebabas in die RSA vertoon 'n unieke kultuur, taal en sosio-emosionele omstandighede. Die vraag ontstaan dus of dit nie ook 'n unieke wyse van ouerleiding impliseer nie. Kan die bestaande inlig- ting oor ouerleiding van blanke gesplete-lip-en-verhemeltebabas sonder meer op hul swart eweknieë toegepas word? Die belang van interkulturele veranderlikes in hulpverlening word tans sterk in die Spraakheelkunde beklemtoon. Wêreldwyd begin spraakheelkundige organisasies hulself ten doel stel om kultureel diverse populasies ten volle te akkommodeer. Daar is reeds in die VSA wetgewing in dié verband ingestel (Taylor, 1986).

Watter unieke kulturele kenmerke en behoeftes kom by die swart Suid-Afrikaanse bevolking voor? Eerstens is kommunikasieprobleme in kruis-kulturele gesondheidsdienste 'n probleem. Daar word tien verskillende swart tale in SuidAfrika gepraat. Engels is dikwels'n tweede of derde taal vir die swart Suid-Afrikaner. In 'n studie wat deur Louw (1986) geloods is oor swart gesplete-lip-en-verhemeltebabas het $76 \%$ van die moeders min of geen Engels verstaan nie en moes daar van 'n tolk gebruik gemaak word om effektiewe interaksie en oordrag te bewerkstellig. Tweedens, ouers wat afkomstig is uit meer tradisionele en ongeletterde agtergronde, neig om kulturele gebruike en bygelowe aan te hang (Smoot, Kucan, Cope en Aase, 1988). Dabuto-Brown (1989) doen verslag dat die tipiese Afrika-kultuur' $n$ baba met 'n erge wanformasie van die gesig, as onaanvaarbaar beskou.

Derdens, 'n aspek wat wetenskaplik moeilik peilbaar is, 
omdat dit in die Westerse kultuur as 'n kriminele oortreding beskou word en dus selde aangemeld word, is kindermoord. Strauss (1985) bevind dat dit dikwels binne 'n Derde Wêreldsamelewing as 'n ritueel of tradisionele prosedure beskou word om ' $n$ baba wat met' $n$ kongenitale afwyking gebore is om die lewe te bring. Verder noem hy dat kinders wat met 'n kongenitale defek gebore word, dikwels as 'n slegte voorbode deur die familie beskou word en dus weggesteek of ver. waarloos word.

Binne die Suid-Afrikaanse konteks word die kliniese waarneming gemaak dat 'n groot persentasie van die swart bevolking oningelig is met betrekking tot die beskikbare mediese ondersteuningsdienste vir 'n baba met gesplete lip en verhemelte. Dit kan daartoe lei dat die ouers glad nie aanmeld vir mediese en ander beskikbare vorme van gespesialiseerde behandeling nie of, soos Dabuto-Brown (1989) aandui, dikwels in 'n baie laat stadium aanmeld vir sodanige hulp vir hulle baba.

Vierdens, word die voeding van swart babas met gesplete lip en verhemelte ook deur kulturele gebruike geraak. Dit is baie belangrik vir 'n swart moeder om haar baba te borsvoed (Louw, 1986). Die babas word dikwels suksesvol geborsvoed sonder 'n voedingsplaatjie of enige gespesialiseerde opleiding. Hierdie verskynsel kan toegeskryf word aan 'n drang om te oorleef en die beskouing dat die aankoop van 'n plaasvervanger vir moedersmelk, 'n onnodige uitgawe is (Louw, 1987). Vyfdens en laastens vertoon swart babas met hierdie gebrek ook eiesoortige ontwikkelingskenmerke (Louw, 1986). Hierdie verskynsel kan moontlik toegeskryf word aan die feit dat die gemiddelde swart moeder in Suid-Afrika dalk nie die volle implikasies van die afwyking besef nie en eerder met die onmiddellike situasie en behoeftes gemoeid is as om toekomsgerig te wees.

Die behoeftes van swart babas in Suid-Afrika wat met'n gesplete verhemelte gebore word, is dus uniek. Hierdie waargenome verskille tussen die blanke en swart populasies noodsaak gevolglik aanpassings aan bestaande dienslewering en vroeë intervensieprogramme (McWilliams, Morris \& Shelton, 1984), sodat dit toepaslik sal wees vir swart gesplete-lip-enverhemeltebabas binne die multikulturele opset in SuidAfrika.

Vanweë die kompleksiteit van die probleem en die nadelige invloed wat ' $n$ gesplete lip en verhemelte op 'n kind se ontwikkeling kan uitoefen (Fox, Lynch \& Brookshire, 1978), beveel outoriteite aan dat vroeë intervensie vir 'n gesplete-lip-en. verhemeltebaba binne spanverband geskied (Bzoch, 1989; Krogman, 1979). MacDonald (1978) meen dat die ouers beskou moet word as baie belangrike lede van die gesplete-lipen-verhemeltespan. Die ouers speel ook by vroeë ingryping ' $n$ kardinale rol. Die doel van vroeë ingryping is eerstens voorkomend en tweedens fassiliterend. Die spraakterapeut bereik die kind indirek deur sy ouers te lei. Suksesvolle ouergesentreerde terapie bestaan uit drie komponente, naamlik inligtingverskaffing (wat weet die ouers?), beraad (hoe voel die ouers?) en opleiding (wat moet die ouers doen?).

Die wyse waarop vroeë intervensie en meer spesifiek ouerleiding plaasvind, wissel van mekaar. Geskrewe materiaal (inligting), byvoorbeeld pamflette (Olmstead, Hardwick \& Fortier, 1980), kan sinvol aangewend word aangesien dit die ouers tyd bied om na te dink oor hulle vrae en die ouers wat buite bereik van 'n spraakterapeut is, van inligting voorsien. Aanpassings in die gebruik van geskrewe materiaal moet egter gemaak word wanneer daar met ongeletterde ouers gewerk word. Pamflette kan as riglyn dien vir die spraakterapeut om inligting oor te dra. Dit word egter in die literatuur beklemtoon dat inligtingverskaffing net 'n onderdeel van 'n ouerlei- dingsprogram uitmaak. Die ander twee genoemde aspekte, naamlik beraad en opleiding, moet ook aandag geniet as die span die ouers en baba ten volle wil ondersteun (Louw, 1988).

Die bepaling van die spesifieke behoeftes van moeders van swart babas met 'n gesplete lip en verhemelte, wat as basis kan dien vir 'n ouerleidinginligtingstuk, kan dus as vertrekpunt dien vir ouerleiding tydens vroeë intervensie met die spesifieke populasie.

\section{METODE}

\section{DOEL}

Die doel van die studie is om 'n effektiewe inligtingstuk oor die gesplete-lip-en-verhemelteafwyking saam te stel wat sosiokultureel toepaslik is vir gebruik deur die plaaslike swart bevolking in Suid-Afrika.

\section{NAVORSINGSONTWERP}

Hierdie studie is in die vorm van 'n tweegroepontwerp, wat 'n tussengroepontwerpmetode is, uitgevoer (Smit, 1983). Die toetspopulasie bestaan uit twee groepe proefpersone, wat op toevallige wyse geselekteer word. Die variansie tussen die twee groepe word ook waargeneem. 'n Onafhanklike veranderlike, naamlik 'n inligtingstuk, word by die een groep ingelyf, terwyl dit nie by die ander groep gedoen word nie. Tussengroepsvergelykings word getref ten opsigte van die veranderlike, naamlik 'n vraelys, wat deur albei groepe beantwoord word.

\section{PROEFPERSOONSELEKSIE}

Die proefpersone was vyftien moeders van swart babas met 'n onherstelde gesplete lip en verhemelte. Hulle is op toeyallige wyse geselekteer in hospitaalklinieke en in twee groepe verdeel. Van Groep 1 word inligting in verband met die moeders se kennis omtrent die gesplete-lip-en-verhemeltegebrek, die behoeftes en probleme wat hulle ondervind, asook die moeder se emosionele belewenis van haar baba verkry. Op grond van die inligting soos verkry van Groep 1 is daar 'n inligtingstuk saamgestel. Groep 2 word benut om die effektiwiteit van hierdie inligtingstuk te evalueer. Proefpersone moes aan 'n SuidAfrikaanse swart groep behoort aangesien die studie gemik is op die saamstel van 'n inligtingstuk vir die moeders van swart Suid-Afrikaanse babas met 'n gesplete lip en verhémelte.

Die babas moes ten tye van die uitvoering van die studie nog geen chirurgiese behandeling vir die gesplete lip en verhemelte ontvang het nie. Die teikenpopulasie van die studie is ouers van jong babas met'n gesplete lip en verhemelte wat behoefte het aan inligting, beraad en opleiding met betrekking tot die hantering van hulle babas. Die babas moes binne die ouderdomsgroep 0 tot 24 maande val. Sodoende het 'n beperkte variasie in terme van behoeftes en ontwikkelingmylpale tussen die babas voorgekom (Anderson, Nelson \& Fowler, 1978). Die babas moes geen ander kongenitale afwyking buiten die gesplete lip en/of verhemelte vertoon nie. Sodoende verkry die steekproef 'n meer homogene aard wat die ken. merke van die babas en die ouers se behoeftes betref (McWilliams et al. 1984). Tabel 1 verskaf 'n opsommende weergawe van die kenmerke van die proefpersone.

\section{MATERIAAL EN. APPARAAT}

\section{Vraelys}

Op grond van reeds geïdentifiseerde vraagtukke en probleme wat algemeen by ouers van babas met gesplete lip en verhemelte presenteer (Massengill \& Phillips, 1975; Mac- 
Tabel 1: Algemene beeld van die proefpersone wat by hierdie ondersoek betrek is.

\begin{tabular}{|c|c|c|c|c|c|}
\hline $\begin{array}{l}\text { PP. } \\
\text { no. }\end{array}$ & $\begin{array}{c}\text { Moeder } \\
\text { skolasties }\end{array}$ & $\begin{array}{l}\text { Kind } \\
\text { geslag }\end{array}$ & $\begin{array}{c}\text { Kind } \\
\text { ouderdom }\end{array}$ & Huistaal & $\begin{array}{c}\text { Tipe } \\
\text { spleet* }\end{array}$ \\
\hline 1 & st. 10 & V & 6 mde & N. Sotho & 1 \\
\hline 2 & st. 2 & V & 8 mde & Shangaan & 5 \\
\hline 3 & st. 1 & V & $1,5 \mathrm{mde}$ & Zoeloe & 3 \\
\hline 4 & geen & V & 8 mde & Zoeloe & 1 \\
\hline 5 & st. 7 & V & 7 mde & Tsonga & 2 \\
\hline 6 & st. 5 & V & 6 mde & Swazi & 2 \\
\hline 7 & st. 2 & V & 5 mde & Zoeloe & 1 \\
\hline 8 & st. 5 & V & 8 mde & N.Sotho & 2 \\
\hline 9 & st. 2 & M & $1 \mathrm{md}$ & S.Sotho & 4 \\
\hline 10 & st. 8 & M & 2 mde & S.Sotho & 5 \\
\hline 11 & st. 3 & $M$ & 5 mde & Zoeloe & 4 \\
\hline 12 & st. 2 & V & 5 mde & S.Sotho & 2 \\
\hline 13 & st. 5 & V & $11 \mathrm{mde}$ & Tsonga & 3 \\
\hline 14 & st. 2 & V & 6 mde & Shangaan & 4 \\
\hline 15 & st. 7 & $\mathrm{M}$ & 3 mde & Zoeloe & 1 \\
\hline
\end{tabular}

- Sleutel tot die klassifisering van tipes splete: (ACPA-klassifikasie, Bzoch,1989).

1 Spleet van die lip en alveolus.

2 Spleet van die velum.

3 Spleet van die palatum en velum.

Unilaterale splete van die lip, alveolus, palatum en velum

5 Bilaterale spleet van die lip, alveolus, palatum en velum.

Donald, 1978; Starr, 1983), is daar 'n vraelys ontwerp vir die peiling van proefpersone se emosionele belewenisse en behoeftes en om hul kennis ten opsigte van hul gesplete-lip-enverhemeltebabas te bepaal. Om die analise van die navorsingsdata te vergemaklik, is die vrae verdeel in vier kategorieë. Op hierdie wyse word daar ook meer struktuur verleen aan die evaluasie-proses (Smit, 1983). Die kategorieë sluit die volgende in:

- Die moeder se kennis aangaande die kind se afwyking en die moontlike oorsake van die gesplete lip en verhemelte by haar kind word geëvalueer.

- Moontlike probleme wat die baba en sy familie kan ondervind as direkte gevolg vari sy gesplete lip en verhemelte word ondersoek. Aspekte wat gedek word, is: gehoor, voeding, kommunikasiegedrag, finansies en kulturele aanvaarding van die baba.

- Daar word bepaal van watter behandelings- en ondersteuningsdienste die moeder kennis dra. Die familie se gevoelens jeens die mediese behandeling word ook ondersoek.

- Laastens word die ouers en direkte familie van die gespeltelip-en-verhemeltebaba selemosionele belewenis van die baba, asook die vooruitsigte met betrekking tot opvolgbehandeling nadat die inisiële chirurgie voltooi is, met behulp van die vraelys ondersoek.

Die navorser voltooi self deur ' $n$ verbale onderhoud, met behulp van 'n tolk indien nodig, die vraelys saam met die moeder van die gesplete-lip-en-verhemeltebaba. Sodoende word 'n groter mate van eenvormigheid verkry in die wyse waarop die vraelys aangebied word (Campbell, 1990).

\section{Inligtingstuk.}

'n Inligtingstuk is saamgestel met die doel om te beantwoord aan die moeders van swart babas met'n gesplete lip en verhemelte se behoefte aan inligting en emosionele ondersteuning, soos reeds geidentifiseer tydens die toepassing van die vraelys op die proefpersone in Groep 1 (sien PROEFPERSOONSELEKSIE).

Die inligtingstuk is saamgestel uit reeds bestaande ouerleidingsprogramme, wat spesifiek ontwerp is vir gebruik tydens ouergesentreerde intervensie binne die gesplete-lip-en-verhemeltepopulasie (Olmstead, Hardwick \& Fortier, 1980; Brookshire, Lynch \& Fox, 1980; MacDonald, 1978). Die bestaande materiaal is aangepas by die swart bevolking in SuidAfrika se spesifieke kulturur, kenmerke en behoeftes, soos bepaal deur 'n literatuurstudie (Louw, 1986; Cole, 1981; Cervenka, 1984; Dabuto-Brown, 1989; Rampp, 1984) en deur die resultate van die bogenoemde vraelys.

Aangesien daar onder die gemiddelde swart bevolking in Suid-Afrika 'n hoër graad van geletterdheid in Engels as in Afrikaans blyk te wees, is die inligtingstuk in Engels geskryf. Daar is gebruik gemaak van prente van swart babas en die inligting is baie konkreet en visueel voorgestel om dit meer toeganklik te maak vir moeders wat nie kan lees nie of nie Engels begryp nie. Die inligtingstuk kan ook met ongeletterde ouers gebruik word, deurdat die spraakterapeut, met behulp van 'n tolk, die inligting verbaal oordra en toelig met die illustrasies wat in die inligtingstuk verskaf word.

Die inligtingstuk bestaan uit vyf afdelings, naamlik:

- Die anatomic van die orofasiale strukture en die aard en oor. sake van 'n gesplete lip en verhemelte.

- Voeding van 'n gesplete-lip-en-verhemeltebaba.

- Kommunikasie- en Taalstimulasie by 'n gesplete lip-enverhemeltebaba.

- Middeloorprobleme by die baba met 'n gesplete lip en verhemelte en die hantering daarvan.

- Die belang van chirurgiese en ortodontiese behandeling vir'n gesplete-lip-en-verhemeltebaba en die belang van gereelde opvolgbehandeling nadat die baba uit die hospitaal ontslaan is.

\section{PROSEDURE}

\section{Data-insameling}

Hierdie studie berus op data wat van twee groepe proefpersone verkry is, naamlik, Groep 1 en Groep 2 (sien PROEFPERSOONSELEKSIE). 
Insameling van data by Groep 1:

- Die proefpersone is by verskeie hospitale en klinieke gekontak en met behulp van 'n opgeleide tolk ondervra.

- Die vraelyste is, met behulp van 'n tolk, mondelings met die proefpersone behandel en deur die navorser self ingevul.

- Daar is doelbewus gepoog om geen leidrade of aanduidinge met betrekking tot die bèantwoording van die vrae aan die proefpersone te verskaf nie. Die antwoorde watgenoteer is, is uitsluitlik die van die proefpersone.

Insameling van data van Groep 2 :

- Die proefpersone in hierdie groep is by dieselfde hospitale en klinieke as in die geval van Groep 1 gekontak.

- Die proefpersone is met behulp van 'n tolk bekendgestel aan die inligtingstuk wat op grond van die bevindinge uit Groep 1 as vraelyste saamgestel is.

- Daar is sorg geneem om te verseker dat die proefpersone die inligting ten volle begryp en alle vrae voortspruitend daaruit is deur die navorser met behulp van die tolk beantwoord.

- Nadat die proefpersone aan die inligtingstuk bekendgestel is, is dieselfde vraelys as wat met Groep 1 uitgevoer is, ongeveer 1 maand later met die hulp van 'n tolk mondelings op die proefpersone in Groep 2 toegepas. Die proefpersone se antwoorde is deur die navorser self aangeteken.

\section{Data-analise}

Die proefpersone se response op die vraelyste is volgens die onderskeie kategorieë waaruit die vraelys bestaan daarna statisties geanaliseer en op grafiese wyše voorgestel. Die betroubaarheid van die intergroepverskille is op statistiese wyse bereken (Fisher se toets: Zar 1984). Die statistiese berekeninge is ook gedoen om vas te stel of die inligtingstuk wat aan die proefpersone in Groep 2 bekendgestel is, voordat hulle die vraelys beantwoord het, wel 'n beduidende verskil in hul kennis omtrent die oorsake, behandeling en die noodsaaklikheid van opvolgondersoeke teweeggebring het.

\section{RESULTATE}

Resultate word weergegee in die vorm van 'n vergelyking tussen Groep 1, wat nie aan die inligtingstuk blootgestel was nie, en Groep 2 wat wel aan die inligtingstuk blootgestel was, se response op dieselfde vraelys.

Tabel 2: Vergelyking van Groep 1 en Groep 2 se kennis oor moontlike oorsake van gespelete verhemelte.

\begin{tabular}{|c|c|c|}
\hline \multicolumn{3}{|c|}{$\begin{array}{c}\text { Proefpersone wat kennis dra omtrent die moontlike } \\
\text { oorsake van gesplete lip en verhemelte: }\end{array}$} \\
\hline Groep 1 $(\mathrm{n}=8)$ & Groep 2 (n=7) & p-waarde \\
\hline $0 \%$ & $80 \%$ & $\begin{array}{c}0,01 \\
\text { Beduidende } \\
\text { verskil }\end{array}$ \\
\hline
\end{tabular}

Soos voorgestel in Tabel 2, dra die proefpersone in Groep 2 beduidend meer kennis van die moontlike oorsake van 'n gesplete lip en verhemelte as die proefpersone in Groep 1. Alhoewel daar nie ' $n$ beduidende verskil is tussen die mate waarin die twee groepe proefpersone hul babas aanvaar nie, is dit tog opmerklik dat $100 \%$ van die proefpersone in Groep 2 geantwoord het dat hulle hul baba aanvaar, terwyl slegs $70 \%$ van die proefpersone in Groep 1 aandui dat hulle hul baba aanvaar (sien Tabel 3). Die twee groepe se antwoorde betreffende hul familielede se aanvaarding van die babas toon 'n verskil van
Tabel 3: Vergelyking van Groep 1 en Groep 2 se aanvarding van hulle gesplete-lip-en-verhemeltebabas.

\begin{tabular}{|c|c|c|}
\hline \multicolumn{3}{|c|}{ Proefpersone wat hul babas aanvaar: } \\
\hline Groep 1 (n=8) & Groep 2 (n=7) & p-waarde \\
\hline $70 \%$ & $100 \%$ & $\begin{array}{c}0,24 \\
\text { Nie-beduidende } \\
\text { verskil }\end{array}$ \\
\hline
\end{tabular}

\begin{tabular}{|c|c|c|}
\hline \multicolumn{3}{|c|}{ Proefpersone wie se families hul babas aanvaar: } \\
\hline Groep 1 $(\mathrm{n}=8)$ & Groep 2 (n=7) & p-waarde \\
\hline $30 \%$ & $40 \%$ & $\begin{array}{c}0,53 \\
\text { Nie-beduidende } \\
\text { verskil }\end{array}$ \\
\hline
\end{tabular}

Tabel 4: Proefpersone se bewustheid van hulp en behandeling beskikbaar vir hul babas.

\begin{tabular}{|c|c|c|}
\hline Groep 1 $(\mathrm{n}=8)$ & Groep 2 (n=7) & p-waarde \\
\hline \multicolumn{3}{|c|}{ Bewus van chirurgiese herstel van die spleet: } \\
\hline $40 \%$ & $100 \%$ & $\begin{array}{c}0,01 \\
\text { Beduidende } \\
\text { verskil }\end{array}$ \\
\hline Bewus van ortodontiese behandeling en voedingsplaatjie:
\end{tabular}

Tabel 5: Vooruitsigte van opvolgbesoeke

\begin{tabular}{|c|c|c|}
\hline Groep 1 (n=8) & Groep 2 (n=7) & p-wạarde \\
\hline $40 \%$ & $100 \%$ & $\begin{array}{c}0,1 \\
\text { Beduidende } \\
\text { verskil }\end{array}$ \\
\hline
\end{tabular}

slegs $10 \%$ wat te wagte kan wees aangesien slegs die moeders in Groep 2 en nie hulle familielede nie, aan die inligtingstuk blootgestel was.

Volgens Tabel 4 is daar ook 'n duidelike verskil tussen Groep 1 en 2 se bewustheid van die hulp en behandeling wat vir hul babas beskikbaar is. Daar was 'n statisties beduidende verhoging van die proefpersone in Groep 2 (wat aan die inligtingstuk blootgestel was) se bewustheid van die volgende vier behandelingsmoontlikhede, naamlik chirurgiese herstel van die spleet, ortodontiese behandeling en/of 'n voedingsplaatjie, mediese behandeling vir middeloorprobleme en voedings- 
en spraakterapie.

Laastens vertoon die vooruitsig van opvolgbesoek (sien Tabel 5) nadat die babas se inisiële behandeling voltooi is, by die proefpersone in Groep 2 ook beduidend beter as by Groep 1. Al Groep 2 se proefpersone antwoord dat hulle sal terugkeer vir verdere behandeling en hulp, terwyl slegs $40 \%$ van die moeders in Groep 1, wat nie aan die inligtingstuk blootgestel was nie, aandui dat hulle sal terugkeer vir opvolgbehandeling.

\section{BESPREKING VAN RESULTATE}

Die resultate wat van die proefpersone in Groep 1 verkry is en die response van Groep 2 op dieselfde vraelys word gesamentlik bespreek. Dit moet deurentyd in gedagte gehou word dat Groep 1 se response 'n weerspieëling is van die ouers wat nog min of geen ouerleiding on tvang het nie. Die proefpersone in Groep 2 het egter voor die invul van die vraelys ouerleiding ontvang deur middel van die verbale gebruik van die inligtingstuk wat ook saamgestel is as deel van hierdie studie. Die inligtingstuk is gebaseer op die behoeftes, soos aangedui deur Groep 1, met die beantwoording van die vraelys.

Ten spyte daarvan dat die diagnose van hulle kind se gebrek deur mediese personeel aan die ouers oorgedra is, blyk dit duidelik uit die resultate dat nie een van die proefpersone in Groep 1 kennis gedra het van die moontlike oorsake van 'n gesplete lip en verhemelte nie. Hierdie bevinding korreleer met resultate van 'n soortgelyke ondersoek wat deur Slutsky (1969) uitgevoer is op moeders van gesplete-lip-en-verhemeltebabas. Daar is bevind dat $76 \%$ van die moeders wat ondervra is pas na die geboortes van hul babas nog nooit van 'n gesplete lip en verhemelte gehoor het nie (McWilliams et al. 1984). McWilliams et al. (1984) maak die stelling dat hoe meer bekend die ouer van 'n gesplete-lip-en-verhemeltebaba met die afwyking is, hoe makliker sal dit vir die ouer wees om daarby aan te pas. Die feit dat die proefpersone in Groep 1 geen kennis gedra het van 'n gesplete lip en verhemelte as 'n kongenitale afwyking nie, dui daarop dat hulle nie genoegsaam bygestaan is ten opsigte van die aanvaarding en begrip van hul babas se geboorteafwykings nie.

Die proefpersone in Groep 2 se basiese kennis aangaande die aard en oorsake van die 'gesplete-lip-en-verhemelteverskynsel was beduidend beter as die basiese kennis waaroor die proefpersone in Groep 1 beskik het. 80\% in Groep 2, teenoor geeneen van die proefpersone in Groep 1 nie, was bewus yan sommige etiologiese faktore wat geassosieer word met 'n gesplete lip en verhemelte. Die in ligtingstuk het dus die ouers in Groep 2 gehelp om 'n wye siening te ontwikkel van die aard en moontlike oorsaak van hul baba se geboorte-afwyking. Ouers behoort die geleentheid te hê 'om inligting oor die moontlike corsake van 'n gesplete lip en verhemelte te ontvang. Sommige ouers is tevrede met bloot algemene inligting, maar ander verlang meer inligting, veral as die afwyking familiaal blyk te wees (Siegel, 1979). Dit is nie die spraakterapeut se rol om genetiese raadgewing te verskaf aan die ouers nie, maar die moontlikheid van die genetiese aard van die spleet en beskikbaarheid van hierdie diens moet aan hulle oorgedra word.

'n Ondersoek na die probleme wat die gesplete-lip-en-verhemeltebabas sowel as hul ouers ondervind het, is met die oog op die saamstel van die inligtingstuk, op Groep 1 se proefpersone geloods. Hul response op die vraelys het getoon dat $70 \%$ van die proefpersone (Groep 1) of hul babas wel direk as gevolg van die gebrek'n probleem ondervind het. Verder het $30 \%$ van die proefpersone meer as een probleem gerapporteer.

Volgens die resultate van die vraelys was die mees pre valente probleem die van voeding. Hierdie bevinding sluit aan by Rampp (1984) se bevinding dat die voeding van hul gesplete-lip-en-verhemeltebaba 'n algemene bekommernis is by die ouers van hierdie kinders. $87 \%$ van die babas wat voedingsprobleme ondervind in hierdie studie het dikwels verstik tydens voeding en $62 \%$ van die wat dikwels verstik, kry ook voedsel in die nasale ruimte tydens voeding. McWilliams et al. (1984) het bevind dat vroeë voedings-ervarings wat' $n$ baba en ouer ondervind hoogs relevant is vir psigososiale sowel as vir spraak- en taalontwikkeling. Voedingsprobleme kan oorkom word deur die nodige inligting oor voedingsmetodes en -hulpmiddels aan die ouers te verskaf en hulle te ondersteun in die uitvoer van hierdie moeilike taak (Louw, 1987). Slegs $10 \%$ van die moeders in Groep 1 was bewus van voedingsterapie (verskaf deur'n spraakterapeut), teenoor $100 \%$ van die proefpersone in Groep 2 wat wel daarvan bewus was. Die moontlikheid dat Groep 2 se ouers dus sal hulp vra en sal terugkeer vir opvolgsessies word dus ook groter as in die geval van Groep 1, wat nie aan die inligtingstuk blootgestel was nie.

Die mediese behandeling vir 'n gesplete lip en verhemelte is 'n voortgesette en duur proses. Aangesien die populasie waaruit die proefpersone geselekteer is oorwegend onder die laer inkomstegroep in Suid-Afrika ressorteer en dikwels nie aan mediese fondse behoort nie, word die moontlikheid vari finansiële probleme by die behandeling van die proefpersone se babas nie uitgesluit nie. Wat interessant is, is dat die proefpersone in Groep 1 se response op die vraelys die teendeel bewys het. $90 \%$ van die proefpersone antwoord dat daar geen finansiële probleme rakende die behandeling van hul gesplete-lipen-verhemeltebabas is nie. Die rede hiervoor blyk te wees dat die provinsiale hospitale voorsiening maak vir pasiënte in die laer in komstegroep. Hospitaalonkoste, konsultasiefooie, mediese behandeling en medikasie word feitlik $100 \%$ deur die staat gesubsideer. Die antwoorde op die vraelys dui verder aan dat die vervoeronkoste van $40 \%$ van die proefpersone in Groep 1 ook deur die hospitaal gedek word. Ambulanse of treinkaartjies word voorsien aan behoeftige pasiënte wat ver van die hospitaal woon. Hierdie vervoerbystand het weer positiewe implikasies wanneer opvolgbesoeke moet realiseer. Ten spyte daarvan dat die baba ' $n$ baie duur behandelingsproses ondergaan, ontvang die ouers van swart gesplete-lip-en-verhemeltebabas bystand om die finansiële las te verlig. Kostefaktore hoef dus nie ' $n$ beperkende faktor in die kind se behandelingsproses te wees nie.

Die moeders en families se emosionele belewing van die baba met 'n gesplete lip en verhemelte en van sy deformiteit is ook met behulp van die vraelys ondersoek. Dit is 'n groot skok vir 'n ouer/ouers om onverwags 'n baba met hierdie geboortedefek te aanvaar en te versorg (MacDonald, 1978). Die navorsingresultate van die proefpersone in Groep 1 korreleer met hierdie stelling. Die effektiwiteit van die behandelingsproses word beslis bevoordeel wanneer die baba se ouers hom of haar ten volle aanvaar (Starr, 1983). Dit is dus noodsaaklik dat die spraakterapeut ondersoek instel na die ouers van hierdie babas se emosionele reaksie op hul baba se geboortedefek en aandag daaraan skenk tydens die verskaffing van inligting aan die ouers. Deur inligting op 'n gestruktureerde en empatiese wyse aan die ouers te verskaf (verkieslik in hulle moedertaal), kry die ouers nie slegs beter insig in hul baba'se afwyking nie, maar word hulle ook gelei na begrip en aanvaarding van hulle eie gevoelens jeens hul baba met 'n gesplete lip en verhemelte (Louw, 1988).

Volgens Krogmann (1979) is die ouers van die baba belangrike lede van die multi-dissiplinêre span. Die ouers se samewerking sal noodwendig verbeter wanneer hulle positief voel oor die behandeling wat hulle baba ontvang. Slegs die helfte van die proefpersone in Groep 1 het positief gevoel oor die 
behandeling wat hul babas gaan ontvang. Dit was egter opmerklik dat $80 \%$ van dié wat positief gevoel het, buitepasiënte was by die Gesplete Gesigsdeformiteite Kliniek van die Departement Kaak-, Gesig- en Mondchirurgie, Universiteit van Pretoria, waar die ouers nou saamwerk met 'n volledige multidissiplinêre span. Die uitgangspunt waarop hierdie navorsingsprojek gebaseer is, naamlik dat vroeë intervensie binne multi-dissiplinêre verband die ouers van jong gesplete-lip-enverhemeltebabas tot voordeel strek, word hierdeur ondersteun (Bzoch, 1989).

'n Verdere aanduiding dat 'n verandering van gesindheid deur effektiewe ouerleiding teweeggebring kan word, is die verskynsel dat $100 \%$ van die proefpersone in Groep 2 (wat blootgestel was aan die inligtingstuk) aangedui het dat hulle positief voel oor die behandeling wat hulle gesplete-lip-enverhemeltebabas gaan ontvang. Dit is egter moeilik om 'n persoon se houding deur middel van 'n enkele vraag en antwoord te evalueer (McWilliams et al. 1984). Die proefpersone se positiewe houding kan aan veel meer as bloot die inligtingsessie toegeskryf word, byvoorbeeld persoonlikheidsverskille tussen die proefpersone in die onderskeie groepe.

Die twee groepe word verder met mekaar vergelyk in terme van die proefpersone se bewustheid van die hulp en behandeling wat beskikbaar is vir hul gesplete-lip-en-verhemeltebabas. Soos deur middel van statistiese berekeninge bevestig, is daar ' $n$ beduidende verskil tussen die proefpersone van Groep 1 en 2 se kennis aangaande die volgende vier aspekte: chirurgiese herstel van die spleet, ortodontiese behandeling en voedingsplaatjies, mediese behastdeling vir middeloorprobleme en voedings-en spraakterapie. Daar was deurlopend 'n hoër mate van bewustheid van beskikbare behandeling vir hulle babas onder die proefpersone in Groep 2 as wat die in Groep 1 getoon het.

Nadat die baba se gesplete lip en verhemelte herstel is, bestaan die kind se behandeling grootliks uit spraak- en taalterapie (Van Riper \& Emerick, 1984). Deurdat die ouers egter reeds deur middel van vroeë intervensie opgelei word om die kind se spraak- en taalontwikkeling optimaal te stimuleer, word latere ontwikkelingsafwykings voorkom (Bloom \& Lahey, 1978). Dit is dus belangrik dat $100 \%$ van die ouers ingelig moet wees omtrent spraak- en taalterapie en nie slegs $10 \%$ soos uit die vraelyste van Groep 1 blyk nie.

Taalverskille tussen die swart ouers van 'n baba met 'n gesplete lip en verhemelte en die oorwegend blanke span medici wat betrokke is by die behandeling van die baba, plaas deurgaans ' $n$ beperking op die interaksie wat tussen hulle kan plaasvind. Die feit dat spraakterapeute wat by hospitale en kliniek met swart pasiënte werk, dikweis'n swart assistent tot hul beskikking het, is dus 'n voordeel binne die vroeë-intervensie-opset. Die spraakterapeut behoort dus, met die hulp van'n opgeleide tolk, soveel as moontlik inligting aan die ouers oor te dra en die kommunikasie tussen die ouers en die res van die multidissiplinêre span te bevorder.

Nog 'n probleem wat direk binne die spraakterapeut se bemoeienis-area val, is die van middeloorpatologie. Geen van die proefpersone in Groep 1 was bewus van mediese behandeling vir middeloorprobleme nie, terwyl $30 \%$ van die proefpersone se babas reeds middeloorontsteking gehad het voor of ten tye van die uitvoer van die studie. 'n Moontlike verklaring vir die ouers se oningeligtheid betreffende middeloorontsteking en die behandeling daarvan, mag wees dat hulle in so 'n mate met die baba se gesplete lip en/of verhemelte gemoeid was, dat hulle nie ag geslaan het op die baba se middeloorprobleme nie. Middeloorprobleme het egter'n hoë prevalensie by gesplete-lip-en-verhemeltepasiënte (Katz, 1987) en die ouers moet beslis tydens ouerleiding daarop attent gemaak word, om sodoende die moontlikheid van 'n latere gehoorverlies en taalagterstand te beperk. Gereëlde besoeke aan gesondheidsklinieke kan byvoorbeeld aangemoedig word in 'n poging om voorkomend op te tree.

Ten spyte daarvan dat die proefpersone in Groep $1 \mathrm{~min}$ of geen kennis gedra het omtrent die wetenskaplik gefundeerde behandeling wat hul babas gaan ontvang nie, het die navors ing wel getoon dat $100 \%$ van die moeders in Groep 1 mediese behandeling bo tradisionele behandeling vir hul babas verkies het. Dit is opsigself' $n$ positiewe bevinding, veral gesien in die lig van Dabuto-Brown (1989) se bevinding dat die ouers van swart babas met'n gesplete lip en verhemelte in die noordelike dele van Afrika, ten spyte van beskikbare mediese dienste, grootliks op tradisionele medisyne vertrou.

Dit is veral belangrik dat die ouers van 'n baba met ' $n$ gesplete lip en verhemelte bewus gemaak word van alle beskik. bare hulpbronne en behandelingsmoontlikhede terwyl hulle nog binne bereik van die spraakterapeut en res van die multidissiplinêre span is. Die ouers wat ver van 'n hospitaal of kliniek woon, kan ook ten tye van die ouerleidingsessie aanbeveel word om terug te keer na die hospitaal, of 'n spraak-en gehoorgemeenskaps-werkster vir verdere hulp en leiding te nader.

Laastens, beklemtoon MacDonald (1978) die belang daarvan dat die ouers ook aktief moet deelneem aan die behandelingsproses. Hulle moet deel hê aan die beslissings rakende die behandeling van hul baba. Dit is nie voldoende dat die ouers van 'n gesplete-lip-en-verhemeltebaba bloot ingelig word oor die behandelingsproses en passief optree nie. Hulle moet in dialoog met die multi-dissiplinère span verkeer en aktief betrokke wees by die hulpverlening aan hulle kind. Die voorafgaande word as ideaal vir samewerking tussen ouers en professionele persone gestel. Aanpassings as gevolg van kulturele verskille sal noodwendig gemaak moet word.

\section{GEVOLGTREKKINGS EN AANBEVELINGS}

Effektiewe ouerleiding bestaan uit inligtingverskaffing, opleiding en beraad (Louw, 1988). Ongeag wanneer die spraak terapeut se eerste ontmoeting met die ouers van 'n gespletelip-en-verhemeltebaba plaasvind, behoort dit 'n opvoedkundige of opleidingsessie te wees (Massengill \& Phillips, 1975). Deur inligting te verstrek aan hierdie ouers help die terapeut hulle om hul kind se geboorte-afwyking en die behandeling wat dit vere is beter te verstaan en ook om hulself makliker met die geboortedefek te versoen. Dit is ook belangrik dat die ouers van die gesplete-lip-en-verhemeltebaba emosionele steun van die res van die multi-dissiplinêre span ontvang (Starr, 1983). Sodoende word die drie basiese beginsels van ouerleiding, naamlik inligtingverskaffing, opleiding en beraad, bereik.

Huidige resultate dui daarop dat taal- en kulturele probleme tot 'n groot mate oorkom kan word en dat effektiewe ouerleiding vir ouers van swart gesplete-lip-en-verhemeltebabas in Suid-Afrika 'n werklikheid kan wees. Hierdie populasie was tot op hede baie verwarloos. Die resultate van die uitvoering van die vraelys met die proefpersone in Groep 1 het bewys dat hulle beslis behoefte het aan inligting, opleiding en beraad betreffende die hantering en behandeling van hul babas. Hierdie bevindinge word ook wyd gesteun deur die literatuur, wat aantoon dat die ouers van gesplete-lip-en-verhemeltebabas wêreld wyd behoefte toon aan meer inligting oor, opleiding in en emosionele ondersteuning met die hantering van hul babas.

Vanuit 'n kritiese oogpunt beskou, is die steekproef wat gebruik is vir die verkryging van die navorsingsresultate egter beperk, in vergelyking met die totale populasie warop die gevolgtrekkings van toepassing is. Tweedens kan die geldig- 
heid van ' $n$ intragroepvergelyking moontlik aanvegbaar wees, siende dat hierdie navorsingsontwerp minder veranderlikes binne die toetspopulasie sou meebring, indien die inligting oor 'n langer tydperk versamel sou word (Smit, 1983).

Dit blyk egter uit die resultate van die studie dat al die proefpersone in Groep 2 wel baat gevind het by die inligting wat aan hulle verskaf is. Die inligtingverskaffing het plaasgevind met behulp van die inligtingstuk wat saamgestel is op grond van die proefpersone in Groep 1 se behoeftes. Die opgestelde inligtingstuk blyk dus ' $n$ bruikbare instrument te wees om die swart ouers van gesplete-lip-en-verhemeltebabas in SuidAfrika van inligting oor hul baba se kongenitale gesigsdeformiteit te verskaf. Opleiding en beraad is ook ingebou in die inligtingstuk ten einde meer effektiewe ouerleiding te bewerkstellig. Die spraakterapeute by hospitale en klinieke kan die inligtingstuk aanwend as vertrekpunt vir 'n ouerleidingsprogram wat daarop gemik is om sowel die ouer as die kind op die lange duur te bevoordeel.

Uit die voorafgaande bespreking blyk dit dus duidelik dat die spraakterapeut in Suid-Afrika' $n$ verantwoordelikheid het betreffende verdere navorsing, die ontwikkeling en die implementering van hulpmiddels om die ouers van swart gespletelip-en-verhemeltebabas op te lei en te ondersteun. 'n Vroeë intervensiebenadering, kan met groot sukses binne hierdie teikenpopulasie toegepas word.

\footnotetext{
*'n Kopie van die saamgestelde inligtingstuk is van die eerste outeur verkrygbaar.
}

\section{VERWYSINGS}

Anderson. D., Nelson, J. \& Fowler, S. (1978). Developmental assessment schema. In W.H. Northcott (red.), Curriculum guide: Hearing impaired children (0-3 years) and their parents. Washington, D.C.: The Alexander Graham Bell Association for the Deaf.

Bloom, L. \& Lahey, M.(1978). Language development and language disorders. New York: John Wiley.

Brookshire, B.L., Lynch, J.I. \& Fox, D.R. (1980). A parent-child cleft palate curriculum. Developing speech and language. Tigard, Oregon: C.C. Publications.

Bzoch, K.R. (1989). Communicative disorders related to cleft lip and palate. 3de Uitgawe Boston: Little Brown.

Campbell, C. (1990). Ouerleiding by swart babas met 'n gesplete lip en verhemelte. Ongepubliseerde voorgraadse navorsingsprojek: Universiteit van Pretoria.

Cervenka, J. (1984). African mask with cleft lip and palate: Cleft Palate Joumal, 21, 38-40.
Cole, L.T. (1981). Blacks with orofacial clefts: The state of the dilemma. Asha, 22, 557-560.

Dabuto-Brown, D.D. (1989). Cranofacial clefts in a black African population. Cleft Palate Journal, 26, 349-343.

Fox, D.R., Lynch, J.I. \& Brookshire, B.L. (1978). Selected developmental factors of cleft palate children between two and thirty-three months of age. Cleft Palate Journal, 15, 239-245.

Katz, J. (1987). Handbook of clinical audiology. 2de Uitgawe. Baltimore: Williams \& Wilkins.

Krogman, W.M. (1979). The cleft palate team in action. In H.K. Cooper (red.), Cleft palate and cleft lip: A team approach to clinical management and rehabilitation of the patient. Philidelphia: Saunders.

Louw, B. (1986). Swart babas met gesplete-lip-en-verhemelte: 'n Morfiofunksionele studie. Ongepubliseerde Doktorale proefskrif: Universiteit van Pretoria. Pretoria: Universiteit van Pretoria.

Louw, B. (1987). Black South African Cleft Palate Infants: A sociocultural perspective. The proceedings of the American cleft palate association 44th anniversary meeting. Texas Maart 1987.

Louw, B. (1988). Vroeë intervensie by jong hoë risikokinders (0-3 jaar). Communiphon, 285, 18-27.

MacDonald, S.K. (1978). Perspectives concerning cleft lip and palate. Massachusets: (Prescription Parents.

Massengill, R. \& Phillips, P.P. (1975). Cleft palate and associated speech characteristics. Nebraska: Cliffs Notes.

McWilliams, B.J., Morris, H.L. \& Shelton, R.L. (1984). Cleft palate speech. St. Louis: Mosby.

Olmstead, P., Hardwick, H. \& Fortier, S. (1980). Alaska cleft lip and palate series. Alaska: Alaska Resource Project.

Rampp, D.L. (1984). Velopharengeal incompetency. A practical guide for evaluation and management. Texas: Pro-ed.

Siegel, B. (1979). A racial comparison of cleft patients in a clinic population: Associated anomalities and recurrence rates. Cleft Palate Journal, 16, 193-197.

Slutsky, H.(1969). Maternal reaction and adjustment to birth and care of cleft palate children. Cleft Palate Joumal. 6, 425-433.

Smit, G.J. (1983). Navorsingsmetodes in die gedragswetenskappe. Pretoria: Van Schaik.

Smoot, E.C., Kucan, J.O., Cope, J.S. \& Aase, J.M. (1988). The craniofacial team and the Navajo patient. Cleft Palate Journal, 25, 395 402.

Starr, P. (1983). Cleft lip and/or palate behavioral effects from infancy to adulthood. Illinois: C.C. Thomas.

Strauss, R.P. (1985). Culture, rehabilitation and facial birth defects: Internal case studies. Cleft Palate Journal, 22, 56-61.

Taylor, O.L. (1986). Treatment of communication disorders in culturally and linguistically diverse populations. Boston: Little Brown.

Toliver-Weddington, G. (1990). Cultural considerations in the treatment of craniofacial malformations in African Americans. Cleft Palate Journal, 27, 289-293.

Van Riper, C. \& Emerick, L. (1984). Speech correction: An introduction to speech pathology and audiology. New Jersey: Prentice-Hall.

Zar, J.H. (1984). Biostatistical analysis. 2de Uitgawe, New Jersey: Prentice-Hall. 